\title{
Measurement of gallbladder volume with ultrasonography in pregnant women
}

\author{
Sait Kapicioglu MD ${ }^{1}$, Sevgi Gürbüz $\mathrm{MD}^{2}$, Ahmet Danalioglu $\mathrm{MD}^{2}$, Ömer Sentürk MD ${ }^{2}$, Mehmet Uslu MD ${ }^{2}$
}

S Kapicioglu, S Gürbüz, A Danalioglu, Ö Sentürk, M Uslu. Measurement of gallbladder volume with ultrasonography in pregnant women. Can J Gastroenterol 2000;14(5):403-405. Fasting and postprandial gallbladder volumes were investigated using ultrasonography in three groups (10 subjects in each) of healthy women: third trimester pregnant women, postpartum women up to 10 days after giving birth and nonpregnant controls. The scans were performed at 09:00 after a $12 \mathrm{~h}$ fast. After the basal measurement was taken, gallbladder volumes were rescanned in 15 min intervals for 60 mins. At the end of this period, all volunteers received a standard liquid test meal, and scans were performed again for $1 \mathrm{~h}$. The mean basal gallbladder volume was $22.2 \pm 4.2 \mathrm{~mL}$ in the nonpregnant (control) group. In the third trimester group, the basal volume was $37.8 \pm 10.5 \mathrm{~mL}-70.5 \%$ higher than in the nonpregnant group $(\mathrm{P}<0.001)$. In the postpartum group, the mean basal volume was $37.9 \%$ lower $(27.4 \pm 6.5 \mathrm{~mL})$ than that of the third trimester group $(\mathrm{P}<0.02)$. This basal volume was $23.6 \%$ greater than that of the control group $(\mathrm{P}<0.05)$. After administration of a test meal, the postprandial gallbladder volumes decreased during the first few minutes compared with baseline values. The volumes decreased by $10.2 \%$ to $39.8 \%(23.5 \pm 7.3$ to $34.0 \pm 10.2 ; \mathrm{P}<0.01)$ in the third trimester group, by $14.9 \%$ to $43.2 \%(16.6 \pm 4.3$ to $23.3 \pm 5.5 ; \mathrm{P}<0.01,0.001)$ in the postpartum group and by $19.2 \%$ to $51.6 \%(11.9 \pm 3.5$ to $17.9 \pm 3.6 ; \mathrm{P}<0.02,0.05$, $0.01,0.001)$ in the control group. Postprandial mean gallbladder volumes of the third trimester $(\mathrm{P}<0.02)$ and postpartum groups $(\mathrm{P}<0.02$ to 0.01$)$ were significantly different from those of the control group. In conclusion, incomplete emptying of the gallbladder after eating during the third trimester of pregnancy may contribute to cholesterol-gallstone formation, and pregnancy may thus increase the risk of gallstones.

Key Words: Gallbladder volume; Pregnancy; Ultrasonography

\section{Mesure du volume de la vésicule biliaire à l'échographie chez des femmes enceintes}

RÉSUMÉ: On a mesuré le volume de la vésicule biliaire à l'échographie avant et après un repas dans trois groupes ( 10 sujets chacun) de femmes en bonne santé : au troisième trimestre de grossesse, jusqu'à 10 jours après l'accouchement et chez des témoins non enceintes. L'examen a été pratiqué à $9 \mathrm{~h}$, après un jeûne de 12 heures. Une fois la mesure de base prise, l'échographie a été répétée aux 15 minutes pendant 60 minutes. À la fin de la période, tous les sujets ont reçu un repas d'épreuve liquide standard, et des mesures ont été effectuées encore durant $1 \mathrm{~h}$. Le volume moyen de la vésicule biliaire au départ était de $22,2 \mathrm{~mL} \pm 4,2$ chez les femmes non enceintes (témoins), tandis qu'il était de $37,8 \mathrm{~mL} \pm 10,5$, soit 70,5\% $(\mathrm{P}<0,001)$ plus gros, chez les femmes rendues au troisième trimestre de grossesse. Dans le groupe de femmes en post-partum, le volume moyen de la vésicule biliaire au départ était de $27,4 \mathrm{~mL} \pm 6,5$, soit $37,9 \%$ plus petit que celui chez les femmes rendues au troisième trimestre de grossesse $(\mathrm{P}<0,02)$ mais $23,6 \%$ plus gros que celui du groupe témoin $(\mathrm{P}<0,05)$. Après l'administration du repas d'épreuve, le volume de la vésicule biliaire a diminué au cours des premières minutes qui ont suivi sa prise, comparativement aux mesures de base. Le volume a diminué de $10,2 \%$ à $39,8 \%$ (de $23,5 \mathrm{~mL} \pm 7,3$ à $34,0 \mathrm{~mL} \pm 10,2 ; \mathrm{P}<0,01$ ) chez les femmes rendues au troisième trimestre de grossesse, de $14,9 \%$ à 43,2 \% (de 16,6 $\mathrm{mL} \pm 4,3$ à 23,3 mL $\pm 5,5 ; \mathrm{P}<0,01$, 0,001 ) chez les femmes en post-partum et de $19,2 \%$ à $51,6 \%$ (de $11,9 \mathrm{~mL} \pm 3,5$ à $17,9 \mathrm{~mL} \pm 3,6 ; \mathrm{P}<0,02,0,05,0,01,0,001)$ dans le groupe témoin. Ainsi, le volume de la vésicule biliaire après le repas chez les femmes enceintes $(P<0,02)$ et en post-partum $(P<0,02$ à 0,01$)$ était passablement différent de celui chez les femmes témoins. On peut donc conclure que la vidange incomplète de la vésicule biliaire au troisième trimestre de grossesse peut favoriser la formation de calculs de cholestérol et que la grossesse en accroîtrait le risque.

${ }^{1}$ Karadeniz Technical University, School of Medicine, Department of Internal Medicine, Section of Gastroenterology, Trabzon; ${ }^{2}$ Social Security Hospital, Istanbul, Turkey

Correspondence and reprints : Dr Sait Kapicioglu, Karadeniz Technical University, School of Medicine, Department of Internal Medicine, Section of

Gastroenterology, 61080 Trabzon, Turkey. Telephone 90-462-325-3011 ext 5550, fax 90-462-325-2270, e-mail zkapicioglu@hotmail.com

Received for publication August 12, 1997. Accepted January 6, 1999 
$\mathrm{I}_{\mathrm{a}}^{\mathrm{n}}$ women the risk of developing gallstones is directly related to their number of pregnancies (1). Two pregnancies increase the risk of having gallstones twofold, and more than four pregnancies nearly quadruple the risk. Although the mechanisms are incompletely defined, significant alterations in the biliary lipid metabolism and gallbladder function occur during pregnancy and may contribute to the increased risk $(2-4)$.

The stasis of lithogenic bile within an enlarged, sluggish gallbladder occurs during late pregnancy and may contribute to the increased risk of gallstones. The results of a recent study suggest that the hypomotility in late pregnancy promotes gallbladder sludge formation (5).

In the present study, we investigated fasting and postprandial gallbladder volumes of three similar groups of healthy, nonobese women: a nonpregnant control group, pregnant women in their third trimester and postpartum women.

\section{SUBJECTS AND METHODS}

The subjects were selected by random sampling. Thirty healthy volunteers (mean age $29.7 \pm 10.01$ years) agreed to participate in the study after the protocol and test procedures had been explained. Written consent from each patient was obtained, and the study was approved by the Ethics Committee of the Social Security Medical Center lstanbul-Göstepe. The nonpregnant women $(n=10)$ were fertile, and the pregnant women $(n=10)$ were in their third trimester. Postpartum gallbladder volumes were measured during the first 10 days after birth.

The subjects were neither ill nor on any medications. All volunteers had normal fasting serum levels of aspartate aminotransferase, alkaline phosphatase and bilirubin. Those with obesity (more than $12 \%$ above ideal weight), weight changes and family history of gallstones were excluded.

The gallbladder volumes were measured by a real time ultrasonograph with a 3.5 or $5 \mathrm{MHz}$ transducer (Siemens Sonoline SL, Germany) (6). The subjects were scanned supine in the right anterior oblique position by a radiologist trained in ultrasonography. The gallbladder was visualized in the longitudinal and transverse planes, and measurements of maximum length, width and height were taken in duplicate. The gallbladder volume was subsequently calculated using the ellipsoid method (volume $=0.52 \times$ length $\times$ width $\times$ height )

The scans were performed at 09:00 after $12 \mathrm{~h}$ of fasting. After the basal volumes were measured, the gallbladder vol- umes were rescanned at 15 min intervals for 60 mins. At the end of this period, all volunteers received a standard liquid test meal (Ensure, Abbott Laboratories Ltd, Montreal, Quebec) that contained 250 calories $/ 250 \mathrm{~mL}$ (16.7\% protein, 30\% fat, $53.3 \%$ carbohydrate), and then scans were performed for $1 \mathrm{~h}$. The results were expressed as mean \pm SD unless otherwise stated. For statistical analyses, the Wilcoxon matched pair signed-rank test or the Mann Whitney $\mathrm{U}$ test was used. The level of significance was set at $\mathrm{P}<0.05$.

\section{RESULTS}

The results are summarized in Table 1 and Figure 1 . The mean basal gallbladder volume was $22.2 \pm 4.2 \mathrm{~mL}$ in the nonpregnant (control) group. In the third trimester group, the basal volume was $37.8 \pm 10.5 \mathrm{~mL}-70.5 \%$ higher than that of the nonpregnant group $(\mathrm{P}<0.001)$. The mean basal volume of the postpartum group decreased to $27.4 \pm 6.5 \mathrm{~mL}(37.9 \%)$ compared with the third trimester group $(\mathrm{P}<0.02)$. This basal volume was $23.6 \%$ higher than that of the control group $(\mathrm{P}<0.05)$. After administration of a test meal, the postprandial gallbladder volumes decreased during the first few minutes compared with baseline values. The volumes decreased by $10.2 \%$ to $39.8 \%(23.5 \pm 7.3$ to $34.0 \pm 10.2)(\mathrm{P}<0.01)$ in the third trimester group, by $14.9 \%$ to $43.2 \%(16.6 \pm 4.3$ to $23.3 \pm 5.5)$ in the postpartum group $(\mathrm{P}<0.001)$ and by $19.2 \%$ to $51.6 \%(11.9 \pm 3.5$ to $17.9 \pm 3.6)$ in the control group $(\mathrm{P}<0.02,0.05,0.01,0.001)$. Postprandial mean gallbladder volumes of the third trimester $(\mathrm{P}<0.02)$ and postpartum groups $(\mathrm{P}<0.02$ to 0.01$)$ were significantly different from those of the control group.

\section{DISCUSSION}

The present study shows that fasting and postprandial gallbladder volumes of third trimester pregnant women were larger than those of the nonpregnant control group. Postprandial volumes of the postpartum group decreased, but these were still greater than those of the control group. Gallbladder volumes were reduced after the test meal within a few minutes compared with baseline. Fasting and postprandial volumes of nonpregnant, pregnant and postpartum subjects were similar $(2,4,7)$.

Because the hormonal changes during pregnancy are complex, it is not possible to identify with certainty the mediator or mediators of the alterations in gallbladder function.

The increase in volume and the reduced emptying are not

TABLE 1

Mean values of gallbladder volume in pregnant women

\begin{tabular}{lccccccccc}
\hline & & \multicolumn{7}{c}{ Mean volume $(\mathbf{m L})$ at different times $(\mathbf{m i n s})(\mathbf{m e a n} \pm \mathbf{S D})$} \\
Groups & Baseline & $\mathbf{1 5}$ & $\mathbf{3 0}$ & $\mathbf{4 5}$ & $\mathbf{6 0}$ & $\mathbf{7 5}$ & $\mathbf{9 0}$ & $\mathbf{1 0 5}$ & $\mathbf{1 2 0}$ \\
\hline Control & $22.2 \pm 4.2^{2}$ & $22.8 \pm 3.4$ & $21.8 \pm 3.4$ & $22.4 \pm 4.2$ & $22.7 \pm 3.8$ & $17.9 \pm 3.6^{*}$ & $17.2 \pm 4.4^{* *}$ & $14.7 \pm 4.4^{* * *}$ & $11.9 \pm 3.5^{* * * *}$ \\
Third trimester & $37.8 \pm 10.5^{\dagger}$ & $38.8 \pm 11.5^{\dagger}$ & $39.5 \pm 12^{\dagger}$ & $39.2 \pm 12.5^{\dagger}$ & $39.9 \pm 12.9^{\dagger}$ & $34.0 \pm 10.2^{\dagger}$ & $33.2 \pm 11.1^{\dagger}$ & $29.6 \pm 8.6^{\dagger}$ & $23.5 \pm 7.3^{+* * *}$ \\
Postpartum & $27.4 \pm 6.5^{\S}$ & $27.3 \pm 5.6^{\S}$ & $27.9 \pm 5.7^{\S \S}$ & $27.3 \pm 5.2^{\S \S}$ & $26.0 \pm 5.5^{\S \S}$ & $23.3 \pm 5.5^{\S \S \S}$ & $20.0 \pm 4.0$ & $17.5 \pm 4.1$ & $16.6 \pm 4.3^{\S \S \S}$ \\
\hline
\end{tabular}

${ }^{*} P<0.05,{ }^{*} P<0.02,{ }^{* *} P<0.01,{ }^{* * * *} P<0.001$ difference from baseline; ${ }^{\dagger} P<0.001$ difference from control; ${ }^{\S} P<0.05,{ }^{\S} P<0.01,{ }^{\S \S \S} P<0.02$ difference from control 
due to alterations in a meal-induced release of cholecystokinin (CCK) (8). Nevertheless, progesterone, a known inhibitor of smooth muscle contractions $(9,10)$, is a likely candidate. One study showed the direct correlation of fasting and residual volumes with serum progesterone concentrations up to $80 \mathrm{mg} / \mathrm{mL}$ (3). However it cannot be concluded that progesterone caused these effects (3). The changes in indexes of gallbladder function may be due to other factors in pregnant women.

During fasting, the partition of bile between the gallbladder and small intestine is determined by the relation of the resistance to the pressure of the sphincter of Oddi, provided by intravesicular pressure, or intraduodenal pressure or both. Because the serum concentration of progesterone-induced relaxation of the smooth muscle increases during a pregnancy, the decreased tone or increased receptive relaxation of the gallbladder may contribute to its enlargement $(11,12)$. It is interesting, however, that although the serum progesterone concentration was twice as high in the third trimester of pregnancy than in the second, the gallbladder volume was the same in both trimesters (2). Gallbladder volume may be the same in both trimesters because it may result from a limited capacity or relaxation, or alternatively it may result from a progesterone receptor change leading to some accommodation.

Increased gallbladder volumes during fasting may be due to decreased water absorption by the gallbladder mucosa. The large amount of water that is normally absorbed from the gallbladder produces an eight- to 10 -fold increase in the concentration of the organic components of bile (13). Water absorption is dependent on the active absorption of sodium that is mediated by the sodium pump in the gallbladder epithelium (14). The activity of the sodium pump believed to be sodium-potassium ATPase may be decreased by estrogens that are present in large concentrations in the serum during late pregnancy (15).

\section{REFERENCES}

1. Barbara L, Sama C, Morselli LAM, et al. A population study on the prevalance of gallstone disease: The Sirmione Study. Hepatology 1987;7:913-7.

2. Braverman DZ, Johnson ML, Kern F Jr. Effects of pregnancy and contraceptive steroids on gallbladder function. N Engl J Med 1980;302:362-4

3. Everson GT, McKinley C, Lawson M, Johnson M, Kern F Jr. Gallbladder function in the human female: Effect of the ovulatory cycle, pregnancy, and contraceptive steroids. Gastroenterology 1982;82:711-9.

4. Kern F Jr, Everson GT, DeMark B, et al. Biliary lipids, bile acids, and gallbladder function in the human female. Effects of pregnancy and the ovulatory cycle. J Clin Invest 1981;68:1229-42.

5. Maringhini A, Marceno MP, Lanzarone F, et al. Sludge and stones in gallbladder after pregnancy. Prevalence and risk factors. J Hepatol 1987;5:218-23.

6. Everson GT, Braverman DZ, Johnson ML, Kern F Jr. A critical evaluation or real-time ultrasonography for the study of gallbladder volume and contraction. Gastroenterology 1980;79:40-6.

7. Ylostalo $P$, Kirkinen P, Heikkinen J, Maentausta O. Gallbladder volume in cholestasis of pregnancy. N Engl J Med 1981;304:359. (Lett)

8. Radberg G, Asztely M, Cantor P, Rehfeld JF, Jarnfeldt-Samsioe A, Svanvik J. Gastric and gallbladder emptying in relation to the secretion of cholecystokinin after a meal in late pregnancy. Digestion 1989;42:174-80.

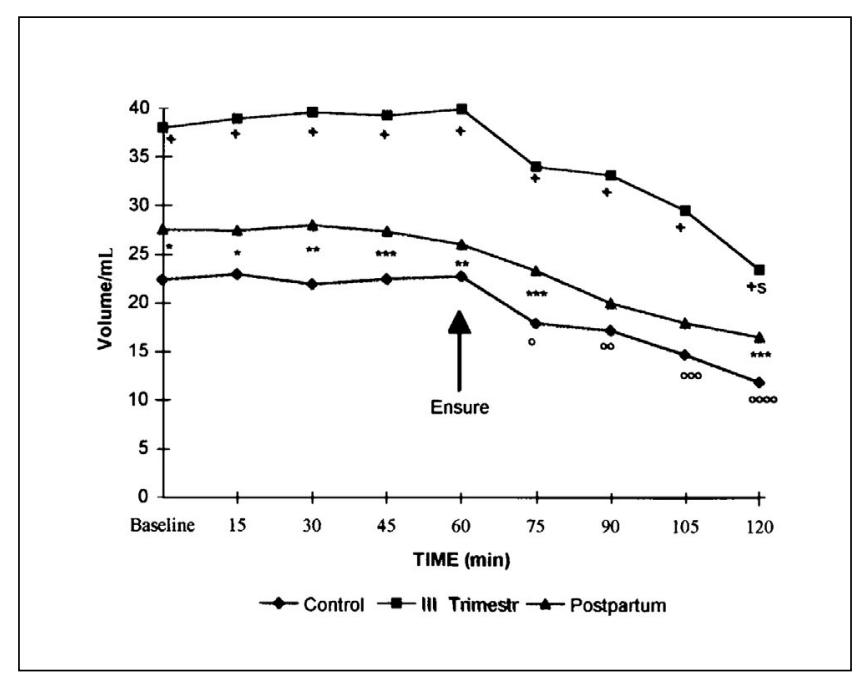

Figure 1) Mean values of gallbladder volume in pregnant women. ${ }^{+} P<0.001$ difference from control; ${ }^{s} P<0.01$ difference from baseline; $* P<0.05, * * P<0.01, * * * P<0.02$ difference from control; ${ }^{\circ} P<0.05$, ${ }^{\circ 0} \mathrm{P}<0.02,{ }^{\circ 00} \mathrm{P}<0.01,{ }^{\circ 000} \mathrm{P}<0.001$ difference from baseline. III Trimestr Third trimester

Gallbladder contractions are mediated via the gastrointestinal hormones CCK and motilin. CCK is the major hormone that mediates postprandial gallbladder contraction (16). The large volume of bile in the gallbladder and the diminished tone of the gallbladder muscle are probably caused by high serum concentrations of estrogens and progesterone, respectively (2).

\section{CONCLUSIONS}

During the third trimester of pregnancy, incomplete emptying of the gallbladder after eating may contribute to cholesterolgallstone formation, and pregnancy may thus increase the risk of gallstones.

9. Schulze K, Christensen J. Lower sphincter of the opossum esophagus in pseudopregnancy. Gastroenterology 1977;73:1082-5.

10. Fisher RS, Roberts GS, Grabowski CJ, Cohen S. Inhibition of lower esophageal sphincter circular muscle by female sex hormones. Am J Physiol 1978;234:E243-7.

11. Crews JK, Khalil RA. Antagonistic effects of 17 beta-estradiol, progesterone and testosterone on $\mathrm{Ca}+2$ entry mechanisms of coronary vasoconstriction. Arterioscler Thromb Vasc Biol 1999; 19:1034-40.

12. Glusa E, Graser T, Wagner S, Oettel M. Mechanisms of relaxation of rat aorta in response to progesterone and synthetic progestins. Maturitas 1997;15:181-91.

13. Diamond JM. Transport mechanism in the gallbladder. In: Code CF, ed. Handbook of Physiology, section 6, vol 5. Washington: American Physiological Society, 1968:2451-82.

14. Van Os CH, Slegers JF. Correlation between $\left(\mathrm{Na}^{+}-\mathrm{K}^{+}\right)$-activated ATPase activities and the rate of isotonic fluid transport of gallbladder epithelium. Biochim Biophys Acta 1971;241:89-96.

15. Davis RA, Kern F Jr, Showalter R, Sutherland E, Sinensky M, Simon FR. Alterations of hepatic $\mathrm{Na}^{+}, \mathrm{K}^{+}$-ATPase and bile flow by estrogen: effects on liver surface membrane lipid structure and function. Proc Natl Acad Sci USA 1978;75:4130-4.

16. Ivy AC, Oldberg E. A hormone mechanism for gallbladder contraction and evaluation. Am J Physiol 1978;86:599-613. 


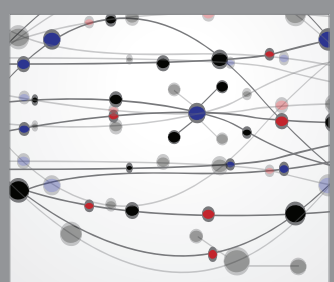

The Scientific World Journal
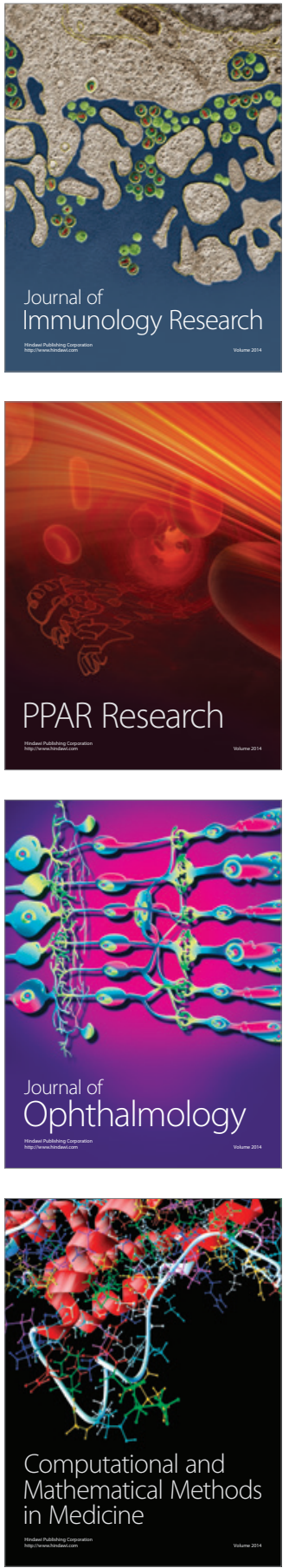

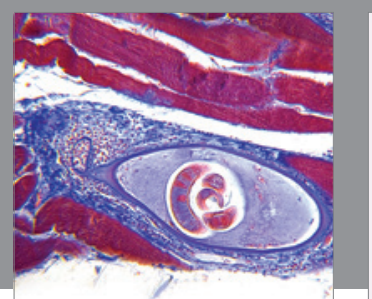

Gastroenterology Research and Practice

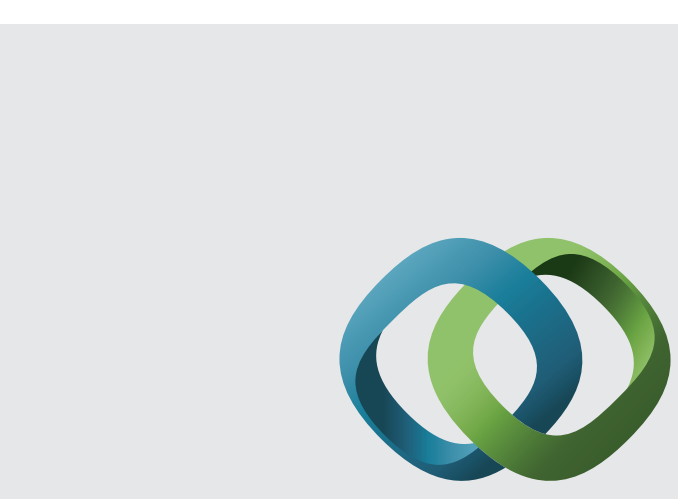

\section{Hindawi}

Submit your manuscripts at

http://www.hindawi.com
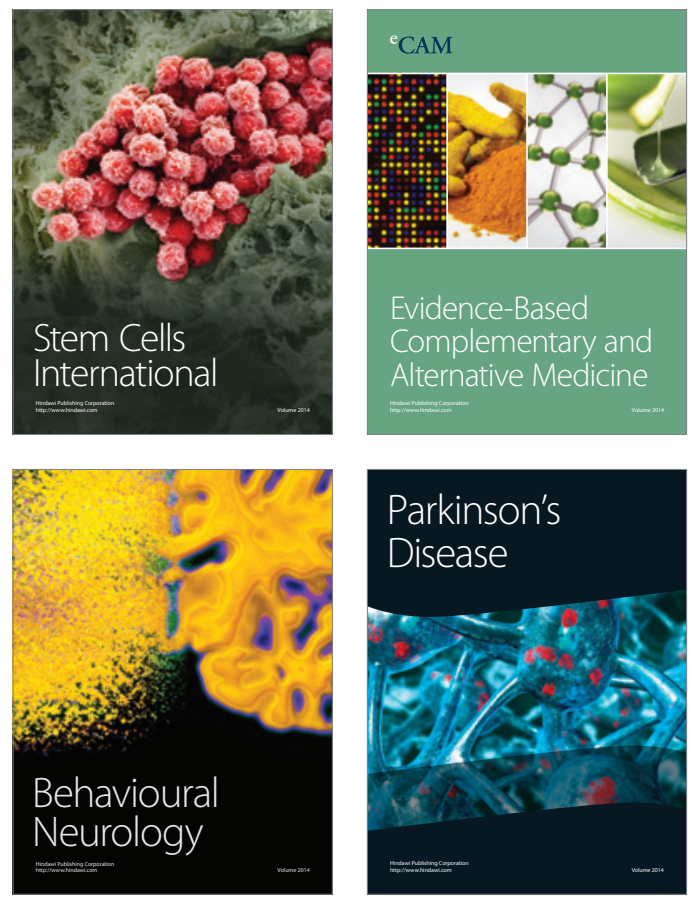
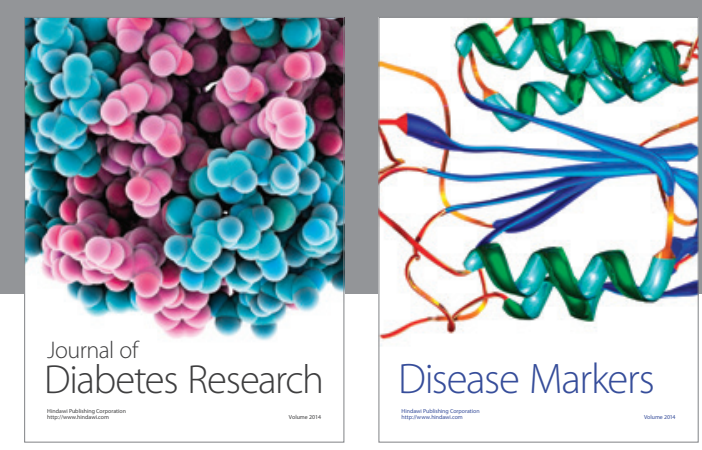

Disease Markers
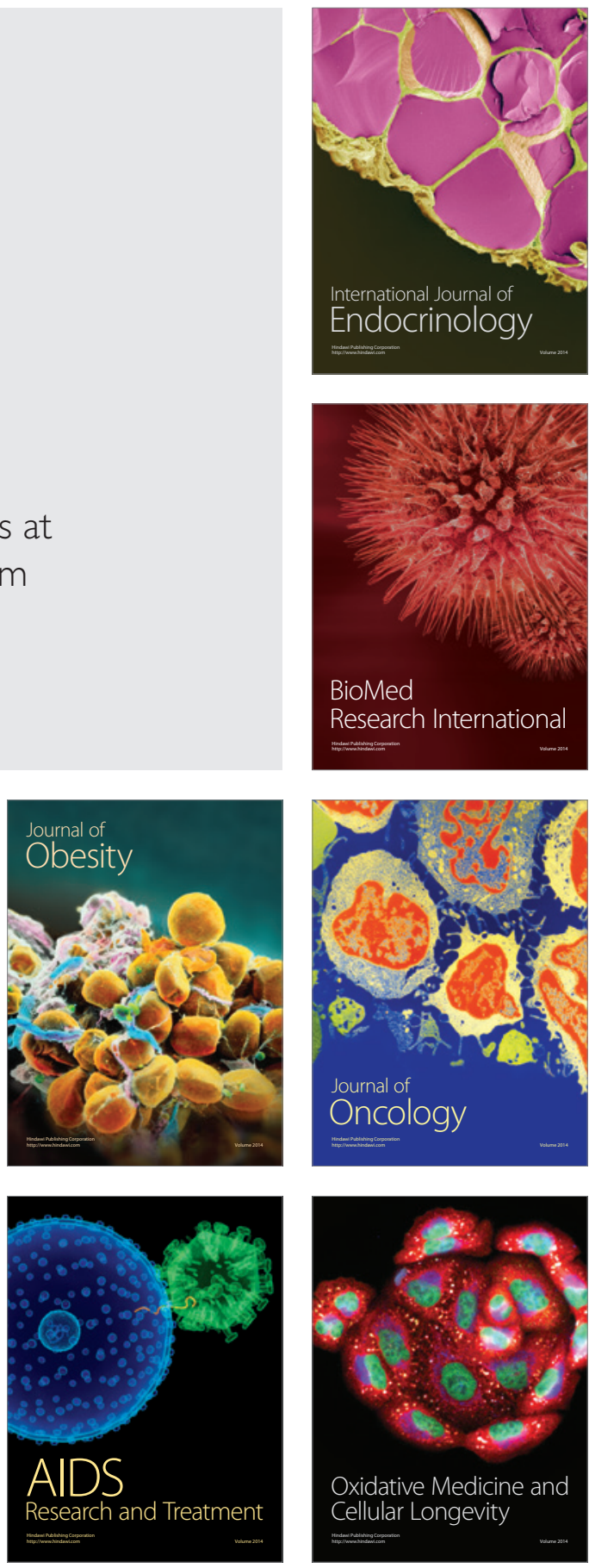